po tal tipo de promoção melhorará sensivelmente as estatísticas educacionais brasileiras. Por outro lado, o prejuízo aos alunos, principalmente aos mais pobres - privados de um reforço educacional que efetivamente eleve seu rendimento escolar -, estará diluído no conjunto das injustiças sociais do país.

Em resumo, pode-se afirmar que o texto aqui resenhado, ao examinar, com extremo cuidado teórico-analítico, a reforma educativa em Portugal, é uma leitura imprescindível não só aos pesquisadores daquele país, mas também aos especialistas do Brasil, interessados em alargar suas análises sobre o acelerado processo de mudanças educacionais atualmente em curso neste lado do Atlântico. Além disso, as muito breves e iniciais comparações - que puderam ser feitas, nos limites deste espaço, a partir da leitura do trabalho de A. J. Afonso parecem atestar que o livro pode ser um eficiente incentivo para um maior intercâmbio entre pesquisadores portugueses e brasileiros.

Dagmar M. L. Zibas

Fundação Carlos Chagas

\section{LINGÜÍSTICA Y ENSEÑANZA DE LA LENGUA}

Marta Marín

Buenos Aires: Aique, 1999, 303 p.

Quem está de algum modo familiarizado com o ensino de língua materna sabe que nas últimas duas décadas processou-se verdadeira revolução nesse campo, pelo menos no plano teórico, cuja contribuição mais essencial veio da lingüística. A professora Marta Marín, especialista em lingüística aplicada ao ensino de línguas, busca aqui apresentar um manual do assunto para um público determinado: os professores de língua materna, já em sala de aula ou em formação. Para os primeiros, atualiza e oferece novas perspectivas de trabalho, para os segundos, propõe de forma integrada e sis- temática o domínio dos conceitos ouvidos em sala de aula.

Não só a clareza e o rigor dos conceitos constituem a grande riqueza desse livro, mas o auxilio que presta aos professores quando oferece exemplos de atividades práticas em sala de aula.

A autora começa por historicizar a tradição mais recente no ensino da língua, desde um enfoque logicista anterior a 60 , centrado no estudo de uma gramática (análise lógico-gramatical), cuja falta de rigor classificatório será resolvida nas décadas seguintes pelo estruturalismo (predominante, de resto, até hoje no esquema brasileiro), do qual a análise sintática é seu viés determinante e mais popularizado. A seguir, procura inserir as distintas teorias lingüísticas que passaram a integrar a prática de ensino da língua nos últimos anos - teorias da comunicação e da enunciação, lingüística textual, pragmática, sociolingüística - no interior de modelos pedagógicos mais amplos, como tem sido o construtivismo, ao mesmo tempo em que busca as intersecções das teorias, de modo a propiciar ao leitor a possibilidade de observar essas teorias como contribuições dentro de um mesmo percurso.

Entretanto, é preciso apontar um outro problema quando a Lingüística se erige - e não sem total razão - em disciplina única para o ensino de língua materna: sem dúvida, ao desbancar a gramática normativa que se detinha exclusivamente na análise e classificação dos termos e das orações e abordar o discurso organizado em texto - que é a unidade mínima para o estudo da língua -, de que partem essas teorias recentes, a lingüística dá passo certeiro, mas não resolve inteiramente o problema, por não conseguir dar respostas satisfatórias num outro aspecto, que é, por exemplo, o ensino da literatura. As teorias da leitura veiculadas mostram-se pertinentes na abordagem de textos não literários e ajudam a tornar funcional para a aprendizagem a gama de textos presentes no cotidiano. Mas a literatura não se deixa aprisionar no pragmatismo dessas abordagens, muito embora estas ofereçam perspectivas mais ricas 
do que certo conteudismo já muito exercitado nas escolas e manuais didáticos.

Dos dois nós do ensino tradicional de língua, a gramática e a história da literatura, estamos em vias de desatar um deles com a contribuição da lingüística, mas o outro permanece inteiramente aberto a buscas, já que não é possível eliminar de todo o historicismo dos estudos literários, mesmo sendo ele tão pouco eficaz - na verdade, da maneira como tem sido perpetrado, é um desastre! Como resolver o problema da história das formas, de seu vínculo com as demais organizações estéticas e sociais de sua época sem cair no mero panorama de estilos, cuja relação com a história é muitas vezes inteiramente arbitrária e forçada, como se vê nos manuais de língua e literatura?

O problema do ensino da língua tem-se colocado para todos os sistemas de ensino ocidentais de hoje, muitas vezes com curiosos resultados, na comparação entre teorias e práticas dos diferentes países. Por exemplo, os nossos Parâmetros Curriculares Nacionais incluíram na sua última versão, como orientação para o ensino de língua portuguesa nos últimos ciclos do ensino fundamental e no ensino médio, uma proposta que, quando incorporada aqui, ainda se encontrava em discussão no seu país de origem, a Suíça. Trata-se da incorporação da noção de gêneros do discurso, segundo perspectiva bakhtiniana, que embora guarde paren- tesco próximo com as tendências em análise e teoria do discurso, não é exatamente a mesma coisa e inclui uma dimensão social da linguagem de que a lingüística não se ocupa, ou se ocupa pouco (a sociolingüística não tem pertinência aí, pois não trata dos níveis do discurso mas dos níveis da fala e de suas variantes).

$\mathrm{Na}$ verdade, defrontamos com uma variedade de aspectos no ensino de língua materna de que só a lingüística não dá conta, por isso este livro é contribuição inquestionável, mas só parcial. Outras áreas, no interior inclusive dos próprios estudos de letras, a teoria literária, oferecem suas contribuições, assim como é preciso trazer também para a prática docente a intuição e a experiência, que a autora parece descartar na mescla a ser considerada ("A docência não é uma mescla de intuição, experiência e 'facilidade natural'; é antes de tudo conhecimento"). Justamente é a experiência que pode levar o professor a considerar diante da classe real as possibilidades de usar, ampliar, transformar ou abandonar determinadas teorias, isto é, não se deixar escravizar por elas, que, como se sabe, ainda continuam apresentando ângulos novos. E, afinal, são teorias, não são métodos.

Neide Luzia de Rezende

Professora de Metodologia do Ensino de Língua Portuguesa - FEUSP 